\title{
INSTALLATION SETS IN TECHNICAL EDUCATION
}

\section{Čestmír SERAFÍN}

Abstract: The article introduces electrical kits in teaching electrical engineering, their optimal use in teaching process and the options for construction of its own resources. Particular emphasis is placed on the area of electrical installation work.

Key words: teaching aids, electrical kits.

\section{ELEKTROMONTÁŽNÍ SOURAVY V TECHNICKÉM VZDĚLÁVÁNÍ}

Resumé: Přispěvek se zabývá elektrotechnickými stavebnicemi ve výuce elektrotechniky, jejich optimálním využití ve výukovém procesu a dále možností realizace stavebnic z vlastních zdrojů. Zvláštni dưraz je položen na oblast elektromontážnich prací.

Klíčová slova: učební pomi̊cky, elektrotechnické stavebnice.

\section{1 Úvod}

Elektrotechnické stavebnice jsou učební pomůcky pro oblast učiva o elektrotechnice a elektronice, které slouži ke zvýšení názornosti a usnadnění učení. Napomáhají tak dosahovat cílů technické výchovy v oblasti elektrotechniky a elektroniky. Jejich prínos je ve vytváření a podpoře technické gramotnosti, technického myšlení, $\mathrm{k}$ rozvoji dovedností i technické tvořivosti. Tyto stavebnice mohou zaujmout již děti ve věku 7 až 8 let a je tedy možné je využívat i na prvním stupni ZŠS.

\section{ELEKTROTECHNICKÉ STAVEBNICE - UČEBNÍ POMŮCKY}

Praktické vyučování technických předmětů se použitím elektrotechnických stavebnic staví do pozice potvrzující slova Jan Ámose Komenského -, ,̌̌kola hrou“. Elektrotechnické stavebnice totiž umožňují rozvíjet nenásilnou formou obecné technické i technologické povědomí žáků, učí je technikám jednoduché experimentální práce (1), (2), rozvíjení pracovních návyků i technické tvořivosti.

Učební pomůcky, kterými jsou i elektrotechnické stavebnice, se vyznačují těsností svého vztahu $\mathrm{k}$ obsahu výuky. Ve vyučovacím procesu působí na učební činnosti žáka prŕmo svými didaktickými funkcemi. Stávají se tak součástí přenosového kanálu mezi učitelem a žákem.

Zařazení elektrotechnických stavebnic do klasifikace pomůcek podle V. Rambouska (3) je možno deklarovat následujícím způsobem (zdůrazněn je čtvrtý bod, který zařazuje elektrotechnické stavebnice př́mo jako speciální pomůcku, ale elektrotechnické stavebnice lze zařadit, jak je doloženo níže, i do dalších kategorií):

1. Originální předmèty a reálné skutečnosti:

a) výrobky a výtvory (jsou i součástí elektrotechnických stavebnic).

2. Zobrazení a znázornění předmětů a skutečností:

a) modely,

b) zobrazení.

2. Textové pomůcky (např. i návodné a učební texty dodávané ke stavebnicím, nebo odkazující na ně)

3. Pořady a programy prezentované didaktickou technikou (napr. software spolupracující se stavebnicí).

4. Speciální pomůcky - žákovské experimentální soupravy.

Podíváme-li se pro srovnání na klasifikaci pomůcek podle D. Hapaly (4), pak vidíme, že elektrotechnické stavebnice lze zařadit př́mo mezi př́istroje (i když je toto zařazení zavádějící vzhledem k pojmovému vymezení př́strojů), ale také, jak je tomu u předchozí klasifikace, lze elektrotechnické stavebnice zařadit i mezi „skutečné předměty“, „symbolické zobrazeniny“ nebo i ,programy“":

1. Skutečné predměty - výrobky (elektrické stroje).

2. Přístroje - demonstrační př́stroje (pro demonstraci měření); př́stroje na měření; soupravy a zařizeni pro frontální pokusy (žákovské soupravy).

3. Zobrazeniny - ilustrace v učebnicích, metodických prŕručkách a návodech; 
4. Symbolické zobrazeniny - schéma zapojení, diagram, graf;

5. - 6. Pomůcky na promítání statických a dynamických obrazů (dataprojektor propojený s počítačem, prrípadně televizní vysílání).

7. Literární pomůcky - učebnice; manuály; metodické príručky.

8. Programy pro vyučovací stroje - software, virtuální elektrotechnické stavebnice.

Zařadíme-li elektrotechnické stavebnice mezi učební pomůcky, pak jim můžeme přiřadit i funkce, které plní ve vztahu k edukačnímu procesu:

1. Funkce motivačně stimulační elektrotechnické stavebnice se mohou při motivaci účastnit $\mathrm{v}$ mnoha směrech. Nejčastěji se využívají $k$ prezentaci měřících a vyhodnocovacích technik. Navíc mohou být zdrojem nových poznatků, na něž může pedagog při vlastní expozici učiva navazovat.

2. Funkce informačně expoziční elektrotechnické stavebnice by měly kvalitně prezentovat obsahové a interpretační informace. Významným aspektem elektrotechnických stavebnic je jejich př́nos ke znázorňování principů. Názornost má různé podoby - přirozená, experimentální, prostorová, zvuková, atd. Elektrotechnické stavebnice používají při zprostředkování jevů a dějů těžko prístupných nebo nebezpečných a skutečností lidskému vnímání nedostupných a neznázornitelných.

3. Funkce procvičovaci - elektrotechnické stavebnice prisspívají $\mathrm{k}$ procvičení a upevnění probraného učiva na nových príkladech a $\mathrm{v}$ nových souvislostech. Elektrotechnické stavebnice se uplatňují při opakování a systematizaci učiva.

4. Funkce aplikační - elektrotechnické stavebnice se uplatňují ve fázi aplikace, tj. při transferu učiva do praxe, při ověřování získaných poznatků $\mathrm{v}$ praxi a při jejich zařazování do širších souvislostí.

5. Funkce kontrolni - kontrola je spjata $\mathrm{s}$ veškerou řídící činností učitele. Pro učitele

i žáka je důležitá zpětnovazební informace. Elektrotechnické stavebnice (zvláště demonstrační) pomáhají při získávání, zpracování a včasném poskytování kvalitních zpětnovazebných informací jak učiteli, tak žákům.
6. Funkce komunikační - elektrotechnické stavebnice vystupují při prezentaci (interpretaci) učiva jako komunikační prostředek, vytvářejí předpoklady pro všestranné zkvalitnění tradiční formy výukové komunikace a pro realizaci její vyšší formy.

7. Funkce racionalizační - tato funkce obecně představuje souhrn organizačních a technických opatření $\mathrm{k}$ nejúčinnějšímu využití pracovní síly, výrobního zařizení, surovin a materiálů, aby se zvýšila produktivita práce. Př́i komplexní racionalizaci vyučovacího procesu mají mimořádný význam právě elektrotechnické stavebnice, které poskytují velice široké možnosti využití.

\section{ELEKTROTECHNICKÉ STAVEBNICE A ŠKOLSTVÍ ČR}

Elektrotechnické stavebnice, používané ve školství, jsou svými vlastnostmi většinou určeny pro fyziku nežli pro všeobecně technicky zaměřenou výchovu nebo zájmovou činnost. Tento stav je dán výrobci stavebnic, kteří se orientují právě na oblast názorné výuky fyziky.

Léta 60. a 70. minulého století se pokládají v Ceskoslovensku za roky velkého rozmachu techniky i technických věd do mnoha odvětví lidské činnosti - to se projevuje $\mathrm{i} v$ prrístupu $\mathrm{k}$ výuce technicky zaměřených předmětů. Vzniká neustálá potřeba nových pomůcek, stavebnic a př́pravků. Školství stálo před problémem jak a čím vybavit žáka ve škole, aby se po jejím absolvování stal platným členem společnosti, schopným držet krok s rozvojem vědy a techniky. Modernizace, která se musela odrazit jak v obsahu, tak v metodice, se opírala o výběr poznatků a jejich uspořádání $\mathrm{v}$ soustavu, která dávala předpoklad nejen ke splnění cílů vzdělávacích, ale která rozvíjela účinně myšlení žáků, jejich praktické dovednosti. Otázka obsahu je stále primární, ale je známo, že ji nelze úspěšně řešit bez ohledu na úroveň a efektivnost vyučovacích metod a prostředků. Klasické metody vyučování byly nahrazovány novým př́istupem $\mathrm{k}$ problematice prostředků vyučování, především názorných učebních pomůcek. Obzvláště pojetí a funkce názorných učebních pomůcek je charakterizována některými specifickými rysy, na jejichž základě se přistupovalo $\mathrm{k}$ modernizaci funkce učebních pomůcek ve vyučovacím procesu. Uplatňovala se dvě hlediska - forma, která je př́mým odrazem současné úrovně vědy a techniky a obsah, který 
je závislý jak na obsahu poznatkové soustavy, tak na pojetí a formě vlastního vyučování. Dále se zdůrazňovalo, že hledisko technické musí být podřízeno požadavku zdůraznění podstatných znaků demonstrovaného jevu, přehlednosti a názornosti experimentu, podněcování myšlení žáků apod. V té době byly distribuovány do škol státním podnikem Komenium stavebnice, které byly orientovány pro elektrotechnické práce žáků (na mnohých školách jsou použivány dodnes). Jednalo se zejména o:

- Elektrotechnickou stavebnici Z 3/III - byla koncipována pro výuku technických prací a technických praktik pro pátý až sedmý ročník základní školy;

- Stavebnici pro technické práce a základy techniky 8. a 9. ročník základní školy - byla určena, jak již vyplývá z jejího názvu, pro technické práce a základy techniky v osmém a devátém ročníku základní školy;

- Elektromontážní souprava - byla rovněž určena pro poslední ročníky ZŠ a je zaměřena na konkrétní aplikační oblasti bytového elektroinstalačního rozvodu;

- Další stavebnice jako Elektronik, MEZ Elektronik, Orion Alfa apod. byly doporučovány pro potřebu zájmové činnosti a rozšíření znalostí a dovedností z probírané látky.

V letech 2005 až 2007 byl na základních školách v České republice realizován průzkum, který se zabýval problematikou elektrotechnických stavebnic z hlediska jejich aplikace v oblasti všeobecně pojatého technického vzdělávání. Byla snaha stanovit obraz o používání elektrotechnických stavebnic na základních školách - zjistit údaje o používání, spokojenosti nebo nespokojenosti s kvalitou a dostupností elektrotechnických stavebnic ve vztahu k vyučovacímu procesu.

$\mathrm{Na}$ obr. 1 je znázorněno rozdělení nejčastějšího používání elektrotechnických stavebnic $\mathrm{z}$ pohledu jejich typologie $\mathrm{v}$ oborovém začlenění. Je zde patrno, že jsou nejčastěji používány stavebnice obecně elektrotechnického charakteru $(37,17 \quad \%) \quad$ a stavebnice elektromontážní $(33,63 \%)$. Součástí průzkumu bylo i zjišt'ování, které elektrotechnické stavebnice se použivají na základních školách a zda si je (nebo alespoň části, funkční bloky, díly apod.) dělají učitelé nebo žáci sami. $Z$ odpovědí respondentů vyplynulo, že pouze $15,93 \%$ dotázaných si vytvárí stavebnice nebo jejich části amatérsky sami a navíc $14,16 \%$ používá ve výuce i pomůcky vyrobené žáky.

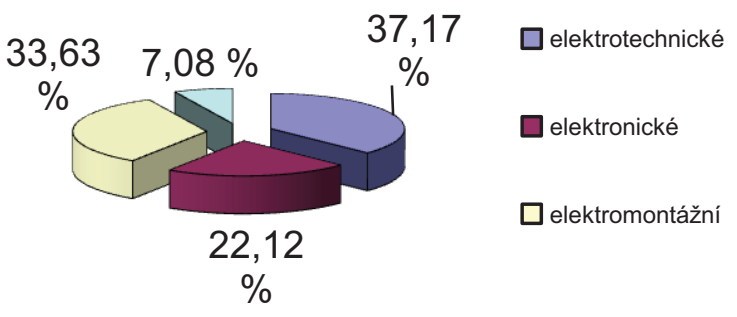

Obr. 1: Oborové členění elektrotechnických stavebnic.

Za nejpoužívanější lze pokládat stavebnice (viz obr. 2):

1. Elektromontážní souprava (33,63\%).

2. Elektrotechnická stavebnice Z3/III (34,51 $\%)$.

3. MEZ elektronik (32,74\%).

4. Elektrotechnická stavebnice pro technické práce $(38,05 \%)$.

V 8,85\% respondenti nebyli schopni určit název stavebnice (ani jejího výrobce) a v 15 prŕípadech (což činí 13,27 \%) nebyl výskyt stavebnice na více školách $\mathrm{v}$ součtu větší než $2 \%$. Tedy př́slušná stavebnice se vyskytovala pouze na jedné nebo dvou základních školách $\mathrm{v}$ regionu.

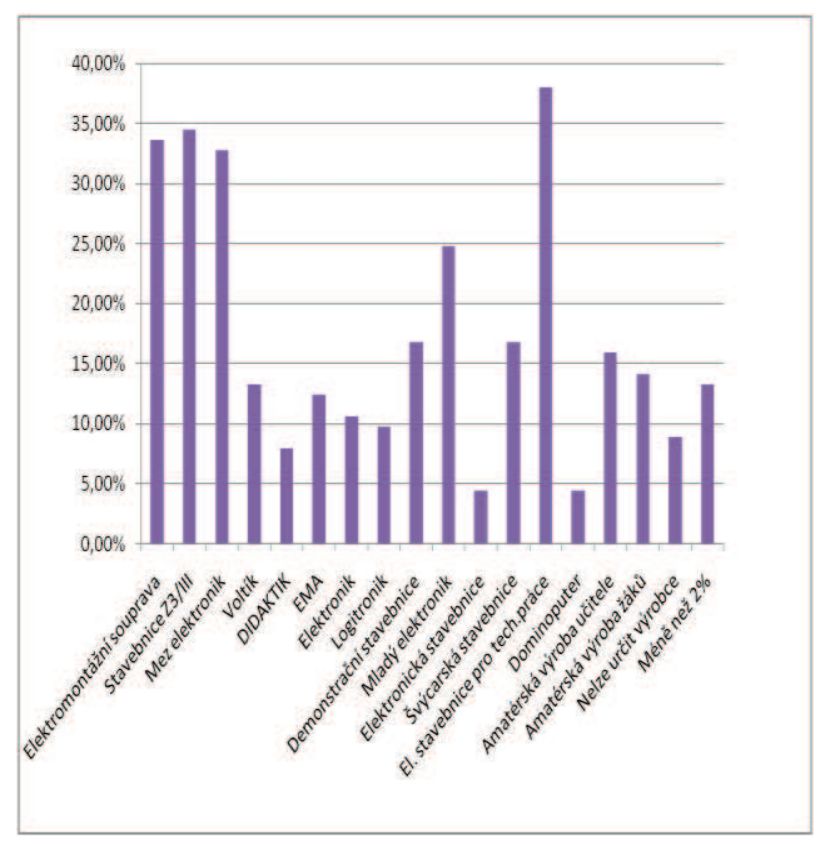

Obr. 2: Přehled elektrotechnických stavebnic použivaných na základních školách. 


\section{Elektromontážní souprava}

Výrobcem elektromontážní soupravy byl v minulém století podnik Dipra v. p. Praha. Jedná se vlastně o velice technicky zajímavou elektrotechnickou stavebnici, která je unikátní v historii elektrotechnických stavebnic v Čechách i na Slovensku. V době svého vzniku vyvolávala vášnivé diskuse, zda takováto stavebnice vůbec patří do výuky základní školy, a to zejména $\mathrm{z}$ bezpečnostního hlediska.

Konstrukčně se jedná o víceúčelovou monotematickou (pouze elektromontážní práce bytové rozvody) a žákovskou stavebnici mající otevřený systém stavebnice. Umožňuje poznat základní a nejjednodušší elektromontážní práce, které se uplatňují v bytovém rozvodu elektrické energie.

Bytový rozvod elektrické energie je součástí elektrorozvodné soustavy s nízkým napětím, které může být svými účinky při nesprávném zacházení člověku nebezpečné. Účelem práce se soupravou není naučit se zřizovat nebo opravovat zařízení bytového rozvodu elektrické energie. Tuto činnost smějí provádět pouze pracovníci s elektrotechnickou kvalifikací. Jedná se zde o způsob poznání, jak jsou elektrické obvody bytového rozvodu zapojeny (vždyt' je denně požíváme) a také jaká technická zařízení jsou určena pro tento účel. Navíc se žáci naučí určité zručnosti při zapojování jednotek představovaných reálnými instalačními prvky (viz obr. 3).

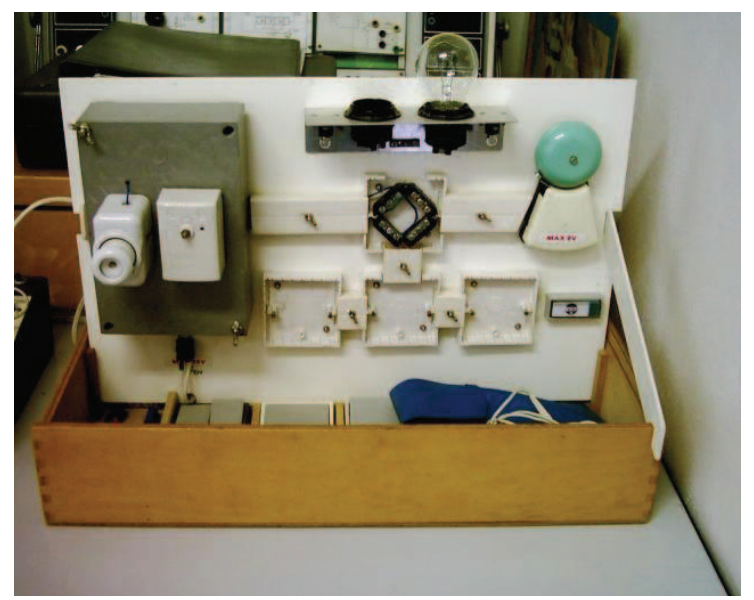

Obr. 3: Elektromontážni souprava.

Napájecí napětí soupravy je $24 \mathrm{~V}$ a je pro dané prostředí a účel pokládáno dle tehdy platných norem za bezpečné. Pro získání přehledu se zapojují obvody podle ustanovení norem platných pro nízká napětí. K ověření funkce obvodů může sloužit i zdroj o napětí 4,5 $\mathrm{V}$ (např. baterie). Kontakty pro přivedení proudu se připojují prŕ́pojnými vodiči s kontaktními nástrčkami, které jsou součástí stavebnice. Druhá strana prípojného vodiče se připojuje ke svorkovnici pod rozvodnou deskou. Veškeré součástky jsou uloženy $\mathrm{v}$ př́íhradovém prostoru (dřevěná krabice) soupravy.

Instalační prvky soupravy jsou shodné $\mathrm{s}$ běžnými součástkami uživanými $\mathrm{v}$ bytovém rozvodu. Tyto ovšem odpovídají elektrotechnickým předpisům ČSN platným v době vzniku stavebnice (zvláště je tato poplatnost doby vzniku stavebnice patrná v oblasti jištění - pojistky). Veškeré součástky, prístroje a spojovací vodiče se ukládají do soupravy podle plánu, který je na vnitřní straně víka. Pro vlastní montáž je vhodné potřebné součástky, nástroje a materiál rozložit mimo soupravu, nejlépe na molitanovou podložku, která je taktéž součástí stavebnice. Pro odkládání matic, šroubů apod. se požívá náhradní krabice pro lištový rozvod.

V př́íslušenství je veškeré potřebné nářadí, elektrická zkoušečka, některé náhradní funkční jednotky (a například i pojistkové vložky) a různě upravené i neupravené vodiče, vše na $24 \mathrm{~V}$, nebo 4,5 V. Stavebnice je určena i pro začátečníky a umožňuje vytvářet realizací elektrických a mechanických spojů jednoduché elektrické obvody - rozvody (zásuvkový obvod, světelné obvody $s$ vypínači a přepínači, obvod s tlačítky a elektrickým zvonkem apod.). Společným konstrukčním elementem je plastová deska $\mathrm{s}$ řadou nepravidelně - podle potřeb jednotlivých obvodů - rozmístěných kruhových otvorů pro přišroubování nosných a instalačních prvků a dílù. Př́i montáži je nutno desku vyjmout $\mathrm{z}$ dřevěné krabice, která tvoří obal stavebnice a svisle ji zasunout do drážek $\mathrm{v}$ této krabici. Elektrické spojení zajišt'ují šroubové spoje a jeden zásuvkový spoj. V návodu přiloženém ke stavebnici jsou kromě situačních schémat uvedeny i fotografie realizovaných obvodů.

Za silné stránky elektromontážní soupravy lze pokládat:

- po technické stránce jde o unikátní provedení, jednoduchou formou zprostředkovává poznatky charakteru elektrotechnického;

- trvanlivý a pevný dřevěný obal;

- kvalitně provedené šroubové spoje (což je dáno i tím, že je použito originálních elektroinstalačních prvků); 
- je otevřená (lze dokoupit řadu elektroinstalačních prvků);

- obsahuje elektrickou zkoušečku;

- koncepce stavebnice i zpracování návodu respektují některé základní didaktické zásady (spojení teorie s praxí, názornost, podněcování aktivity, přiměřenost věku);

- realizovaná zapojení jsou přehledná a jednoduchá;

- rozvíjí technickou tvořivost.

Za slabé stránky elektromontážní soupravy lze pokládat:

- použitý elektroinstalační materiál má technické parametry na úrovni doby vzniku stavebnice (lze inovovat, ale s ohledem na použité napájecí napětí $24 \mathrm{~V}$, resp. 4,5 V některé soudobé prvky nelze použít například stmívače, dálkově ovládané vypínače apod.);

- nelze realizovat zapojení podle současně platných norem (použití chráničů a jističů opět $\mathrm{s}$ ohledem na napájecí napětí $24 \mathrm{~V}$, resp. 4,5 V);

- ochrana před nebezpečným dotykovým napětím je demonstrována jako ochrana nulováním s dvouvodičovým rozvodem, tato ochrana se podle současných platných norem už nedoporučuje a rozvody se realizují tř́vodičově;

- při práci s nářadím je nutný dozor dospělé osoby (nůž by však bylo možné nahradit prŕípravkem pro odizolování vodičůu);

- šroubové spoje v elektroinstalačních prvcích (ve vypínačích, zásuvkách apod.) jsou z hlediska své konstrukce a použitých materiálů určeny pro jednorázové, nebo méně časté mechanické práce. Ve školní praxi tedy vykazují poměrně častou poruchovost (odlomení částí) ;

- umožňuje poměrně malý počet realizovaných obvodů a není v důsledku své koncepce (včetně návodu) př́liš vhodná pro problémové vyučování;

- vznáší otázku, zda je vhodná pro výuku na základní škole, zda téma elektromontážní práce mají zde svůj význam;

- stavebnice vyžaduje velkou manuální zručnost (nevhodná pro manuálně méně nadané žáky nebo tělesně handicapované).

\section{NÁVRH A REALIZACE STAVEBNICE „BYTOVÉ ROZVODY“}

Každá stavebnice $\mathrm{z}$ hlediska školní praxe musí vykazovat určité vlastnosti, které podmiňují její použitelnost. Jednou $\mathrm{z}$ hlavních oblastí je samozřejmě odolnost, zejména odolnost proti zásahům velmi nekvalifikovaným at' už po mechanické stránce (ohyb, krut, odolnost proti pádům a nárazům apod.), tak po stránce elektrické (přepětí, zkrat) a bezpečnost (je třeba si uvědomit, že se stavebnicí budou manipulovat především děti) (5).

Mezi další oblast patří zejména společný konstrukční díl stavebnice, který ovšem není nutnou součástí. Jeho provedení často splývá s propojovací jednotkou, která, jak už bylo řečeno, má velmi velký vliv na mnoho oblastí činnosti se stavebnicí. Provedení tohoto konstrukčního dílu je velmi rozmanité, od dřevěných nebo plastových či papírových desek, přes rozmanité provedení kontaktních polí až po magnetické tabule nebo vodící lišty.

$\mathrm{K}$ dalším neodmyslitelným vlastnostem patř́ hmotnost a rozměr stavebnice, ale také její design (atraktivnost v mnohém rozhoduje o snadnější prístupnosti a je rozhodně lépe přijímána jak žáky, tak také učiteli). A v neposlední řadě i hledisko didaktické (6).

$Z$ výše uvedeného lze přistupovat i k vlastní realizaci stavebnice. Prioritní účel byl vytvořit stavebnici jako moderní protiváhu k „Elektromontážní soupravě“. Konstrukce měla být řešena jako jednoduchá, levná a snadno použitelná, jako pro učitele, tak pro žáka.

Základním konstrukčním elementem navržené stavebnice se stala dřevěná krabice, příčně dělená do tří částí (obr. 4) na část, kde se umistují spotřebiče, část pro zdroj a propojovací prvky a na část kde jsou ovládací prvky. Když žáci sestavují obvod podle zadaného schématu, dávají jednotlivé moduly do těchto částí podle předešlého rozdělení. Například: žárovku nahoru, doprostřed zdroj a krabicovou svorkovnici a dolů spínač. Toto rozdělení je velmi výhodné pro přehlednou práci se stavebnicí. Žáci si upevní tímto způsobem různý význam částí obvodu a jejich společné znaky. Na obr. 5 je uvedeno schéma jako prríklad realizace práce se stavebnicí a jeho transformace $\mathrm{v}$ montážní schéma. Výsledná realizace je pak uvedena na obr. $5 \mathrm{c}$.

Ve stavebnici je jeden zdroj napětí stejnosměrného proudu, který má $4,5 \mathrm{~V}$, je tedy bezpečný pro samostatnou práci žáků. Zdroj má trri vývody, jež simulují skutečnou sít' - tři vodiče: L, PE, N. Tento zdroj je jištěný pojistkou, stejně jako jsou jišstěny bytové rozvody ve skutečnosti (jistič ani chránič z důvodu malého napětí nelze použít). Dále stavebnice obsahuje spínače používající se v běžné elektrotechnické praxi. Je 
to zároveň i velmi dobrý motivační prvek, protože žáci rádi poznávají, jak fungují věci kolem nich, které osobně používají. Součástí jsou zde i dvě krabicové svorkovnice pomocí, kterých budou žáci zapojovat obvody a nakonec jako spotřebič je použita žárovka a dvě zásuvky. Všechny tyto instalační prvky včetně zdroje jsou připevněny na plastové destičky, na kterých jsou svorky vyvedeny na zdířky. Pro spojení se používají propojovací vodiče s banánky.

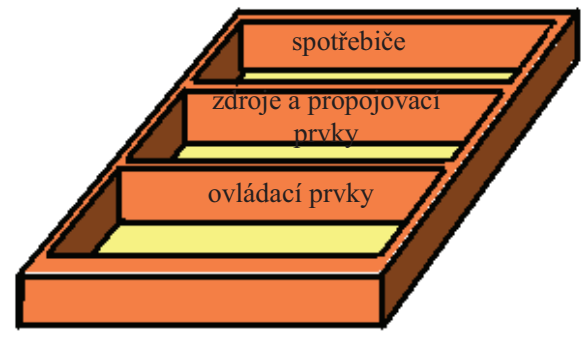

Obr. 4: Konstrukční řešení stavebnice.
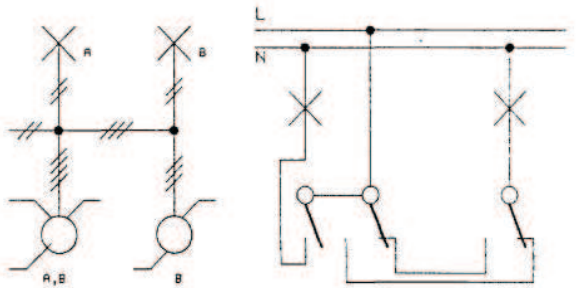

a)
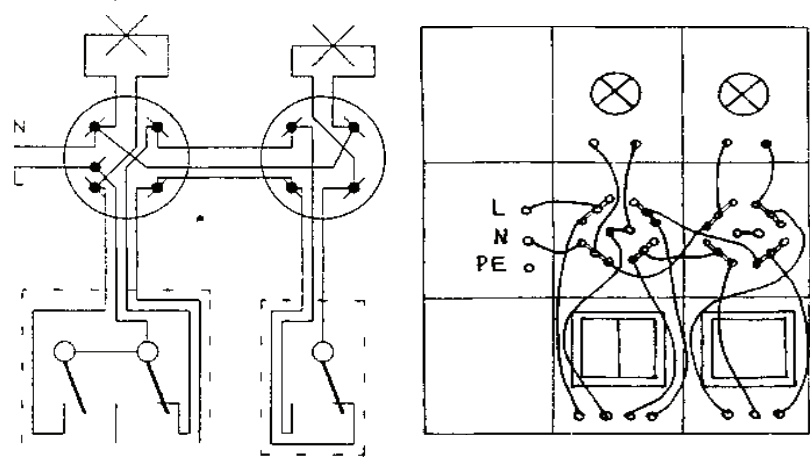

b)

\section{ZÁVĚR}

Elektrotechnické stavebnice jsou jednou z nejdůležitějších učebních pomůcek při výuce elektrotechnicky zaměřených témat. Názornost a tvořivost, jako současný nástroj snadnějšího chápání probíhajících dějů, které jsou ve většině príípadů v elektrotechnice neviditelné, je proto z pozice pochopení uváděné látky tím nejdůležitějším co učitel může při předávání informací pro své žáky udělat.

\section{LITERATURA}

1. ČERVENKA, J., JANDA, O., KŘENEK, M. - ROTHANZL, B. Praktické činnosti elektrotechnika kolem nás pro 6. - 9. roč. ZŠ. Praha : FORTUNA 1997.

2. KŘENEK, M., KOTRBOVÁ, A. Elektronika $v$ technických pracích 8. ročníku ZŠ. Praha : SPN 1985.

3. RAMBOUSEK, V. a kol. Technické výukové prostředky. 1. vyd. Praha: SPN, 1989.

4. HAPALA, D. Materiálne didaktické prostriedky a vzdelávaní dospelých. 1. vyd. Bratislava : OBZOR, 1983.

5. FESZTEROVÁ, M. Bezpečnost' a ochrana zdravia pri práci v laboratóriách. Nitra : UKF, FPV, 2008. s. 17-18, 62-64. ISBN 97880-8094-384-4.

6. DOSTÁL, J. Elektrotechnické stavebnice (teorie a výsledky výzkumu). Olomouc : Votobia, 2008. 74 s. ISBN 978-80-7220-3086.

Doc. Ing. Čestmír Serafín, Dr.,

Katedra technické a informační výchovy, Pedagogická fakulta, Univerzita Palackého v Olomouci, Žižkovo nám. 5,

77140 Olomouc,

Tel. +420584565801

Mail. cestmir.serafin@upol.cz.

Www pracoviště: www.kteiv.upol.cz

Obr. 5: Realizace práce se stavebnicí. a) obvodové schéma, b) montážni schéma c) realizace. 